\title{
ARTYKUŁY
}

Magdalena Heruda y - Ki ełczew ska (Poznań)

\section{Powstanie domu akademickiego przy Wałach Leszczyńskiego $6^{1}$}

Dzieje szkolnictwa wyższego w Poznaniu były przedmiotem niejednej naukowej publikacji ${ }^{2}$, jednak mało miejsca poświęcano w nich życiu społeczności studenckiej, a przecież jest to niewątpliwie barwny i ciekawy do badania temat. Dokumenty, które zachowały się w Archiwum Uniwersytetu im. Adama Mickiewicza, pozwalają dzisiaj zrekonstruować przebieg procesu budowlanego oraz regulaminu, jaki miał obowiązywać w jednym z domów akademickich - zaprojektowanym przez znanego poznańskiego architekta (głównego architekta Powszechnej Wystawy Krajowej oraz autora m.in. projektu budynku Poznańskiego Towarzystwa Przyjaciół Nauk) Rogera Sławskiego i wybudowanym pod adresem Wały Leszczyńskiego 6 (dzisiaj al. Niepodległości 26).

Poznań długo czekał na uniwersytet. Gdy w końcu w 1919 r. otwarto Wszechnicę Piastowską, która rok później zmieniła nazwę na Uniwersytet Poznański, zapisało się na nią dwa tysiące osób i liczba ta stale rosła ${ }^{3}$. Uczelnia

${ }^{1}$ Artykuł jest poprawioną wersją tekstu, który ukazał się na łamach portalu Histmag.org.

2 Alma Mater Posnaniensis. W 80. rocznice utworzenia Uniwersytetu w Poznaniu, pod red. P. Hausera, T. Jasińskiego, J. Topolskiego, Poznań 1999; Munera Posnaniensia. Księga pamiatkowa Uniwersytetu im. Adama Mickiewicza w Poznaniu dla uczczenia 600-lecia zatożenia Uniwersytetu Jagiellońskiego, pod red. G. Labudy, Poznań 1964; B. Miśkiewicz, Uniwersytet Poznański: przeszłość, teraźniejszość, przyszłość, Poznań 1977; B. Miśkiewicz, Uniwersytet im. Adama Mickiewicza: 1919-1989, Poznań 1989; Jubileusz 90-lecia Uniwersytetu im. Adama Mickiewicza w Poznaniu: święto akademickiego Poznania, pod red. M. Kalawskiej, Poznań 2009; Dzieje Uniwersytetu im. Adama Mickiewicza: 1919-1969, pod red. Z. Grota, Poznań 1972; W hotdzie naszym Antenatom: 85 lat Uniwersytetu im. Adama Mickiewicza, pod red. J. Laskowskiego i G. Łukomskiego, Poznań 2004.

${ }^{3}$ G. Labuda, Uniwersytet Poznański w latach 1919-1969, „Kronika Miasta Poznania” 1969, nr 2, s. 12. 
szybko zaczęła borykać się z trudnościami lokalowymi. Rosła potrzeba pomieszczeń dydaktycznych, mieszkań dla pracowników oraz schronienia dla studentów ${ }^{4}$. Zaczęły zapadać decyzje o budowie kolejnych gmachów dla katedr, które potrzebowały tego najbardziej. Walczono również o pozyskanie budynków należących do miasta, takich jak zamek cesarski, które mogły pomieścić sale wykładowe. Wybudować trzeba było również domy akademickie dla studentów spoza Poznania. To jednak nie było wcale proste.

W 1923 r. powołano organizację, która miała odegrać znaczącą rolę w rozwiązaniu problemów bytowych studentów. Poznański Komitet Wojewódzki do Spraw Pomocy Polskiej Młodzieży Akademickiej reprezentował wszystkie warstwy społeczne ${ }^{5}$. Na jego czele stanął wojewoda poznański - Adolf hr. Bniński. Jako cele komitetu uznano:

„a) akcję mającą na celu zakładanie Kół Akademika.

b) zasilanie produktami żywnościowymi kuchni Bratniej Pomocy, co wpływało na obniżenie ceny wydawanych posiłków.

c) bezpłatne pomieszczanie niezamożnej Młodzieży w czasie wakacyjnym na letniskach i prowadzenie kolonij letnich.

d) organizowanie wespół z Młodzieżą imprez dochodowych m.in. »Tygodni Akademika «.

e) subwencjonowanie organizacyj samopomocowych i udzielanie indywidualnych doraźnych zapomóg.

f) wybudowanie »Domów Akademickich «"6.

Punkt ostatni uznano za najważniejszy postulat do zrealizowania, podkreślając, że Poznań nigdy nie miał wyższej uczelni, toteż brakowało odpowiednich budynków, odmiennie niż $\mathrm{w}$ innych miastach uniwersyteckich, gdzie takie domy istniały od dziesiątków lat i były zamieszkiwane z pokolenia na pokolenie. Pomysł wybudowania od razu jednego dużego akademika padł już na spotkaniu założycielskim Komitetu w październiku 1923 r. W rok później prezes Komitetu zwrócił się do Wydziału Robót Publicznych przy Urzędzie Wojewódzkim, aby wykonano kosztorys budynku, który mógłby pomieścić około trzystu studentów. Z Poznańskiego Komitetu wyłonił się Komitet Budowy Domu Akademickiego w Poznaniu, na czele którego stanął prof. Adam Wrzosek. Pozostawało jeszcze wybrać teren pod budowę domu. Komitet Poznański za dogodne miejsce uznał poforteczne grunty przy Wałach Leszczyńskiego ${ }^{7}$.

${ }^{4}$ P. Hauser, T. Kotłowski, Uniwersytet Poznański w latach 1923-1939, w: Alma Mater Posnaniensis, s. 141.

${ }^{5}$ Dziatalność Poznańskiego Komitetu do spraw pomocy Polskiej Młodzieży Akademickiej w latach 1923-1934, Poznań 1935, s. 5.

6 Tamże, s. 12.

7 Tamże, s. 23-24. 
W marcu 1925 r. UP wystąpił do Komisji Rozbudowy Miasta Poznania o przyznanie owej parceli pod budowę Głównego Domu Akademickiego8. Teren ten przeznaczony był pierwotnie na potrzeby Ministerstwa Skarbu, pod budowę gmachu Banku Polskiego. W związku z czym wojewoda poznański zwrócił się do Ministerstwa Robót Publicznych o cofnięcie wcześniejszego rozporządzenia9. W czerwcu Senat uczelni uchwalił postanowienie, aby od nowego roku akademickiego przeznaczać czesne i wpisowe z części studenckiej na potrzeby budowy domu ${ }^{10}$. Z kolei Poznański Komitet Wojewódzki do Spraw Pomocy Polskiej Młodzieży Akademickiej zaciągnął kredyt na budowę akademika w Banku Cukrownictwa ${ }^{11}$. Kredyt miał być spłacany przez Uniwersytet, ale to Komitet Wojewódzki (a ściślej mówiąc Komitet Budowy Domu Akademickiego w Poznaniu) był, powiedzielibyśmy dzisiaj, wykonawcą przedsięwzięcia. Zadeklarował on zresztą, że Uniwersytet stanie się właścicielem budynku (ewentualnie miał on przejść na własność Skarbu Państwa) ${ }^{12}$. W tym miejscu zaczyna się niezbyt jasna procedura podejmowania szeregu decyzji na temat budowy. Zresztą sam Rektor UP stwierdził w 1938 r., że odbyło się to „bez formalnego załatwienia sprawy przewłaszczenia"13. Od marca $1926 \mathrm{r}$. UP zaczął przekazywać pieniądze do Banku Cukrownictwa na rachunek Wojewódzkiego Komitetu do Spraw Pomocy Młodzieży Akademickiej. W tym samym czasie tenże Komitet pisał do radcy prawnego: „Nominalnym właścicielem budującego się domu akademickiego ma być Uniwersytet, względnie Skarb Państwa (Uniwersytet), wobec tego uważam, że Ministerstwo Robót Publicznych może wprost przydzielić omawiany teren pod budowę, nie czyniąc tego ani w formie sprzedaży, ani też dzierżawy. Budynek będzie bowiem właściwie państwowy, w użytkowaniu Uniwersytetu dokąd ten istnieje [...]. Proszę o wyjaśnienie powyższego Ministerstwu, ewentualnie proszę skłonić Ministerstwo o prowadzenie pertraktacji dotyczących dzierżawy lub sprzedaży terenu z Uniwersytetem, jako

8 Archiwum UAM, sygn. 15/308, Rektorat, Dom Akademicki przy Wałach Leszczyńskiego 6 1925-1931, 2 marca 1925 r.

9 Tamże, 8 kwietnia $1925 \mathrm{r}$.

${ }^{10}$ Tamże, 12 czerwca 1925 r. (Na początku roku akademickiego uiszczało się wpisowe, sumy przeznaczane były na domy profesorskie i akademickie. Za ćwiczenia w pracowniach i seminariach były osobne opłaty na potrzeby tychże. Za egzaminy też były osobne opłaty. Niezamożna młodzież mogła mieć odroczone pozostałe opłaty, ale wpisowe było obowiązkowe. Art. 92 Ustawy z dnia 13 lipca 1920 roku o szkołach akademickich.

11 Poznański Komitet Wojewódzki zwrócił się do sześciu największych poznańskich banków z prośbą o kredyt na budowę, jednak tylko Bank Cukrownictwa udzielił zgody. Pozostałe tłumaczyły się trudnościami finansowymi. Działalność Poznańskiego Komitetu, s. 25.

12 Archiwum UAM, sygn. 15/308, Rektorat, Dom Akademicki przy Wałach Leszczyńskiego 6 1925-1931, 22 września 1925 r., 10 grudnia 1925 r.

13 Archiwum UAM, sygn. 15/303, Rektorat, Budowa domu akademickiego UP 1930-1939, 25 IX 1938. 
właścicielem, [względnie] Komitetem po osiągnięciu przez niego osobowości prawnej"14.

Mechanizmy finansowania i wydaje się, że sama budowa również, zostały już uruchomione, choć własność nie była jeszcze określona. Jak wynika z korespondencji prowadzonej pomiędzy uczelnią z Komitetem do Spraw Pomocy Młodzieży Akademickiej, wiosną prace były już dosyć zaawansowane. W liście z czerwca, w którym Komitet prosił o wpłacenie dziesięciu tysięcy na konto w Banku Cukrownictwa (zresztą Komitet co jakiś czas prosił kwesturę Uniwersytetu o kolejne sumy pieniędzy), informował, że prace murarskie sięgają już drugiego piętra ${ }^{15}$. Wcześniej, w kwietniu, Ministerstwo Robót Publicznych wyraziło zgodę na przydział parceli przy Wałach Leszczyńskiego pod budowę domu akademickiego ${ }^{16}$. W grudniu 1925 r. stan budowy miał się przedstawiać w taki sposób: „Do budowy Głównego Domu akademickiego [...] zwieziono 680000 cegły, ugaszono 600 etn. Wapna, wykopano fundamenty i wbito $\mathrm{w}$ terenie nie dość spoistym, przedstawiającym zasypane rowy forteczne, 250 sztuk pali betonowych oraz wykonano 7 betonowych filarów $80 / 80 \mathrm{~cm}$ na starych murach pofortecznych, przyczep ciąg dalszy prac odłożono do lutego $1926 \mathrm{r.}{ }^{\prime 17}$

$\mathrm{W}$ istocie więc rozpoczynano wszelkie prace zmierzające do jak najszybszego postawienia domu, przechodząc ścieżkę formalności administracyjnych w tym samym lub późniejszym czasie.

Pod koniec maja 1926 r. Komisja dla Rozbudowy Miasta Poznania przekazała Uniwersytetowi teren ten $\mathrm{w}$ bezpłatne użytkowanie pod budowę domu akademickiego, natomiast wszelkie ciężary publiczno-prawne miały przejść na UP ${ }^{18}$. Okazuje się jednak, że sytuacja była dość skomplikowana. Tytuł własności należał bowiem tymczasowo do Wojewódzkiego Komitetu do Spraw Pomocy Polskiej Młodzieży Akademickiej, a dom nie został wpisany do księgi wieczystej ponieważ czekano na zakończenie akcji budowlanej ${ }^{19}$.

Pierwszą część akademika oddano do użytku w maju 1927 r. i już zamieszkali tam studenci. W 1928 r. Komitet Wojewódzki prosił Bank Gospodarstwa Krajowego w Warszawie o kolejny kredyt, w wysokości 500000 zł (rok wcześniej wnioskowano z sukcesem o 500000 zł). Komitetowi zależało na jak najszybszym otrzymaniu pieniędzy, aby w całkowicie wykończyć dom tak z zewnątrz, jak i wewnątrz. W roku następnym bowiem miała odbyć

${ }^{14}$ Archiwum UAM, sygn. 15/308, Rektorat, Dom Akademicki przy Wałach Leszczyńskiego 6 1925-1931, 24 III 1926.

15 Tamże, 15 czerwca $1926 \mathrm{r}$.

16 Tamże, 16 kwietnia $1926 \mathrm{r}$

17 Działalność Poznańskiego Komitetu, s. 30.

18 Archiwum UAM, sygn. 15/308, Rektorat, Dom Akademicki przy Wałach Leszczyńskiego 6 1925-1931, 27 maja $1926 \mathrm{r}$.

19 Tamże, 30 lipca $1928 \mathrm{r}$. 
się Powszechna Wystawa Krajowa, a nowy dom akademicki był potrzebny dla przyjęcia wycieczek studenckich i akademickich oraz zapewnienia niedrogiego posiłku ich uczestnikom ${ }^{20}$. „Echo Powszechnej Wystawy Krajowej" informowało, że dom studencki będzie oferował trzysta pokoi i trzy duże sale ${ }^{21}$.

Wykończony budynek oddano pod koniec kwietnia 1929 r. w zarząd Bratniej Pomocy. Ze względu na Pewukę dom uroczyście poświęcono na początku nowego roku akademickiego - 27 października. Mszę św. w kaplicy Domu Akademickiego odprawił prymas August Hlond w obecności przedstawicieli władz państwowych i samorządowych, Senatu Akademickiego, studentów oraz ofiarodawców. Wiceprezes Poznańskiego Komitetu ks. prałat Józef Prądzyński wezwał młodzież do tego, aby dom akademicki był dla nich nie tylko mieszkaniem, ale także kuźnią talentów chrześcijańskich i narodowych. Wojewoda Bniński podkreślił, że akademik powstał dzięki ofiarności społeczeństwa Wielkopolski. Rektor Uniwersytetu prof. Stanisław Kasznica podziękował Komitetowi i zwrócił się do młodzieży, by mieszkając w tym miejscu, przyzwyczajała się do życia samorządnego, natomiast prezes Bratniej Pomocy podziękował za dowód życzliwego zainteresowania dolą studenta ${ }^{22}$.

Ostatecznie organizacja domu przedstawiała się następująco:

„Oficyna: [...]

16 pokoi 3 osobowych $=48$ łóżek

7 [pokoi] 2 [osobowych] = 14 [łóżek]

1 [pokój] 1 [osobowy] = 1 [łóżko]

Razem 24 pokoi z ogółem 64 kwaterami

[...] Ponadto 5 pokoi biurowych, fryzjernię, korytarze, ustępy i klatkę schodów.

Gmach główny I i II część: [...]

179 pokoi jednosobowych $=179$ łóżek

39 [pokoi] dwuosobowych $=78$ [łóżek]

1 [pokój] trzyosobowy = 3 [łóżka]

2 [pokoje] czteroosobowe $=8$ łóżek

Razem 221 pokoi z ogółem 268 łóżek

Ponadto:

2 sale jadalne

Czytelnia, kaplica ${ }^{23}$

${ }^{20}$ Archiwum UAM, sygn. 15/308, Rektorat, Dom Akademicki przy Wałach Leszczyńskiego 6 1925-1931, 19 lutego $1929 \mathrm{r}$.

21 „Echo Powszechnej Wystawy Krajowej” 1928 (1 kwietnia), nr 4, s. 1.

22 Działalność Poznańskiego Komitetu, s. 51-52.

${ }^{23}$ Kaplica znajdowała się w dużej sali, która na co dzień pełniła funkcję czytelni. Ściany zostały wyposażone w specjalne szafy, w których na czas nabożeństwa za drewnianymi żaluzjami 
Kuchnia centralna z pomieszczeniami gospodarczemi, pralnia, prasowalnia

Mieszkanie Pana Kuratora

3 mieszkania 2 pokojowe $\mathrm{z}$ kuchnią

1 mieszkanie 3 pokojowe bez kuchni

Mieszkanie dla żeńskiej służby kuchennej, portiernia, poczta, centralne ogrzewanie, warsztaty, hole, łazienki, ustępy, korytarze, 4 klatki schodowe, magazyny, piwnice i góry do bielizny. [...]

Kuchnia centralna zaopatrzona jest $\mathrm{w}$ urządzenie gazowe o sześciu kotłach parowych pojemności ogólnej 1500 litrów, z kotliną, piekarnikiem i podgrzewaczem. Ciepły wody dostarczają dwa zbiorniki z których jeden ma połączenie z kotliną i kotłami dla wyzyskania ciepła gazu spalinowych, drugi ogrzewany jest małem piecykiem koksowym.

Wydajność kuchni obliczona jest jednorazowo na 1000-1200 porcji obiadowych.

W dwu salach jadalnych może zasiadać od razu 186 osób stołujących się przy 48 stołach.

Czytelnia pomieści przy 34 stołach 82 osoby" ${ }^{24}$.

Budynek musiał prezentować się bardzo okazale. Jego cechą charakterystyczną była zresztą monumentalność, czerpiąca ze stylów historycznych, co było charakterystyczne dla projektów Rogera Sławskiego w tamtym okresie. Dom zbudowano jako czteroskrzydłowy, rozplanowany na rzucie prostokąta i przykryty wielospadowym dachem. Charakterystyczny był kolumnowy portyk zwieńczony tympanonem. Zgodnie z projektem, powstało pięć kondygnacji, z których ostatnia została oddzielona mocno wysuniętym gzymsem. Dwa skrzydła budynku wysunięto przed elewację frontową i tylną. Budynek cofnięto w stosunku do ulicy, więc przed jego frontem znajdował się niewielki skwer ${ }^{25}$.

Oceniano, że budowa odbywała się z wielkim wysiłkiem. Sporo bowiem było przerw w pracach spowodowanych brakiem pieniędzy i kłopotami z dostaniem kredytu, ciężkimi zimami, który wyrządzały szkody w systemie instalacyjnym ${ }^{26}$. Koszty budowy obu części domu, wraz z urządzeniem kuchni, budową Domu Medyków, kosztami umeblowania i budowy obejścia, wraz z odsetkami wyniosły, według książek kasowych kierownictwa budowy, 2529 040,10 zł. Koszty pokrywano z kredytów oraz z Funduszu Opłat

chowano czasopisma, z których korzystała młodzież. Podobnie w ścianie chowany był ołtarz. Działalność Poznańskiego Komitetu, s. 33.

${ }^{24}$ Archiwum UAM, sygn. 15/308, Rektorat, Dom Akademicki przy Wałach Leszczyńskiego 6 1925-1931, 23 kwietnia 1929 r.

${ }^{25}$ G. Klause, Roger Stawski, 1871-1963. Architekt, Poznań 1999, s. 90, 179.

${ }^{26}$ Archiwum UAM, sygn. 15/308, Rektorat, Dom Akademicki przy Wałach Leszczyńskiego 6 1925-1931, 23 kwietnia 1929 r. 
Studenckich i różnego rodzaju subwencji, m.in. z powiatów i miast województwa poznańskiego 27. Przyznany z banku kredyt wyniósł 1250000 zl, co według Komitetu, było i tak mniejszą sumą niż kredyty udzielone na budowy akademików w innych miastach ${ }^{28}$.

Jak wyglądało życie codzienne studentów w tym akademiku, możemy się jedynie domyślać. Pomocny w tym rozmyślaniach będzie regulamin z kwietnia 1927 r. Przed wprowadzeniem się do Domu Akademickiego należało przedstawić świadectwo zdrowia, a $\mathrm{w}$ razie zachorowania trzeba było zawiadomić gospodarza piętra, który z kolei musiał to zgłosić kuratorowi Domu. Kurator natomiast był władny nawet oddać chorego studenta do szpitala. Nakazywano bezwzględne utrzymanie porządku, a w razie zniszczenia sprzętu w pokojach trzeba było zapłacić za ich naprawę.

Za niedopuszczalne uznawano powrót w stanie nietrzeźwym, co mogło zakłócić spokój. Cisza nocna obowiązywała od 23.00 do 7.00. Ponad to w kwestii stosownego i cichego zachowania zaznaczano również: „Dom akademicki zamyka się o 12 w nocy; wracający później do domu sygnalizują swój powrót dyskretnie oraz płacą stróżowi nocnemu 20 groszy gotówką"29.

Opuszczając dom, nie wolno było zabierać ze sobą kluczy do pokojów, konieczne więc było zostawianie ich w portierni. Portier z kolei mógł wymagać okazania legitymacji mieszkańca akademika. Zabronione było oddawanie i zamiana pokoi. Ponieważ był to męski dom studencki, kobiety nie miały do niego wstępu. Goście mogli odwiedzać mieszkańców do godziny 22.00, a więc przyjmowanie kogokolwiek na noc było niedopuszczalne. Ewidencja gości musiała być zresztą bardzo dokładnie prowadzona.

Prawdopodobnie $\mathrm{w}$ domu pracowały osoby zajmujące się sprzątaniem pokoi. Jeden z punktów regulaminu bowiem głosił, że między 9.00 a 13.00 należało „dać sposobność" ich uporządkowania.

Domem miał opiekować się kurator mianowany na sześć lat przez Senat Akademicki. Otrzymywał on bezpłatnie mieszkanie, światło i opał. Decydował sam o dalszym personelu, wybierając wedle swojego życzenia portiera, gospodarza domu (również spośród studentów) i osoby sprzątające. Obowiązkiem gospodarza było prowadzenie wykazów: mieszkańców domu, petentów, starających się o mieszkanie, byłych mieszkańców, wydalonych $\mathrm{z}$ domu z podaniem przyczyny wydalenia. Kurator z kolei miał prawo veta wobec zgłoszonych kandydatur na mieszkańców (kandydatury zgłaszała korporacja studencka Bratnia Pomoc). Sam również mógł przyjąć wedle własnego uznania niewielką liczbę studentów. Przysługiwało mu prawo wyda-

27 Archiwum UAM, sygn. 15/303, Rektorat, Budowa domu akademickiego UP 1930-1939, 1 maja $1936 \mathrm{r}$.

28 Archiwum UAM, sygn, 15/308, Rektorat, Dom Akademicki przy Wałach Leszczyńskiego 6 1925-1931, 10 lutego $1929 \mathrm{r}$.

${ }^{29}$ Tamże, 12 kwietnia 1928 r. 
lenia mieszkańca, wglądu w biurowość domu oraz oględzin pokoju o każdej porze, nawet pod nieobecność studentó $w^{30}$.

Nietrudno domyślić się, że reguły życia w przedwojennym akademiku odbiegały swoją surowością od obecnych. Nie ma się zresztą czemu dziwić, zadaniem zarządu domu bowiem było dbanie o odpowiednią postawę moralną, zgodną z ówczesnym modelem wychowania.

Nie wiemy dzisiaj, ile kosztował pokój. W Poznaniu miesięczny koszt wynajmu umeblowanego pokoju w domu akademickim kosztował wówczas od 50 do 100 zł, co było dla studenta sporym wydatkiem ${ }^{31}$. Zachowały się zdjęcia $\mathrm{z}$ tego okresu, które pokazywały wygląd pomieszczeń. Wydaje się, że urządzenie ich było dosyć komfortowe. W pokoju jednoosobowym mieściły się: metalowe łóżko, stolik nocny, stół, szafa, krzesło, fotelik i umywalka. Umeblowanie pokoi miały fundować osoby prywatne i w tym celu wydano do społeczeństwa stosowną odezwę ${ }^{32}$. Nie dysponujemy księgami meldunkowymi mieszkańców akademika, trudno więc stwierdzić, kto (np. z późniejszej kadry UP i UAM) tam mieszkał ani co pisano w podaniach o przyznanie miejsca. Zupełnym luksusem dla historyka byłoby zapewne znalezienie np. jakichkolwiek wspomnień studenckich czy jadłospisów stołówki. Póki tego nie mamy, możemy sobie jedynie wyobrażać życie codzienne $w$ takim miejscu.

$* * *$

Do września 1939 r. kwestia przynależności domu do Uniwersytetu nie była wyjaśniona. W 1928 r. Komitet Wojewódzki do Spraw Pomocy Polskiej Młodzieży Akademickiej zobowiązał się, że po zakończeniu budowy przewłaszczy on grunt wraz z domem Uniwersytetowi Poznańskiemu na jego żądanie. Z kolejnych dokumentów wynika, że tak się jednak nie stało ${ }^{33}$. Cztery lata później pojawił się pomysł zakupienia budynku i gruntów, na których akademik jest postawiony. Senat Akademicki porozumiał się nawet $\mathrm{w}$ tej sprawie z Komitetem Wojewódzkim, który odniósł się przychylnie do pomysłu, ale zastrzegł, że chciałby mieć wpływ na wewnętrzne sprawy domu. Ministerstwo Skarbu wyraziło zgodę na sprzedaż parcel państwowych, na których postawiony jest Główny Dom Akademicki za cenę 30\% ceny szacun-

30 Tamże, 2 marca $1927 \mathrm{r}$.

${ }^{31}$ Działalność Poznańskiego Komitetu, s. 24.

32 Tamże, s. 34.

33 Archiwum UAM, Sygn. 15/308, Rektorat, Dom Akademicki przy Wałach Leszczyńskiego 6 1925-1931, 31 października 1928 r. 


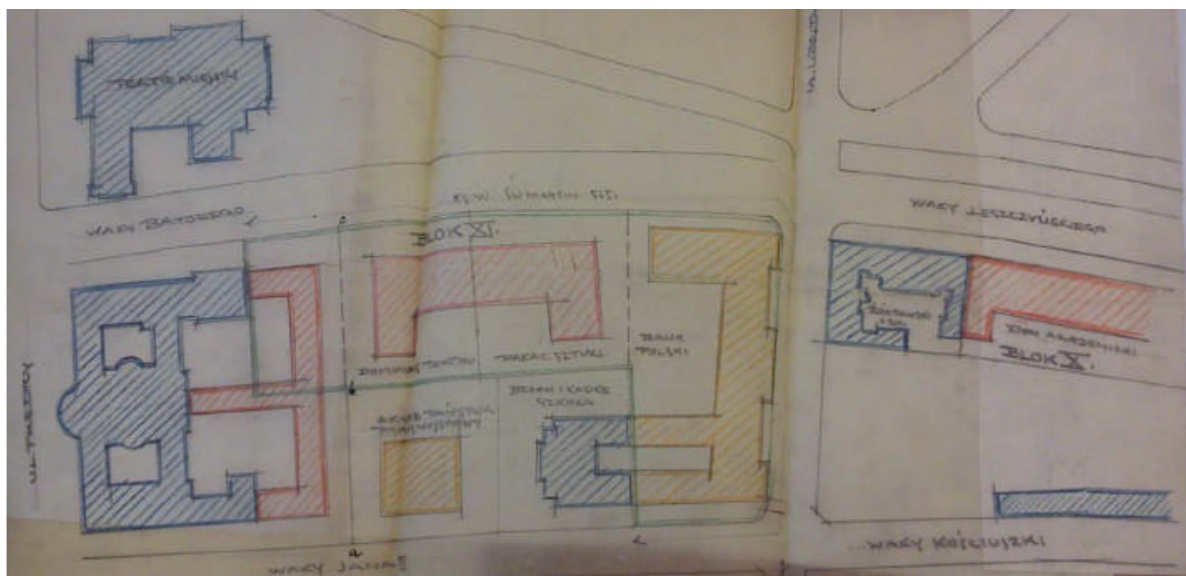

Ryc. 1. Rok 1925. Szkic rozbudowy terenu zaproponowany przez Uniwersytet Poznański. Z lewej strony Collegium Medicum z planem rozbudowy zaznaczonym na czerwono. Dom akademicki zaznaczony jako Blok X. Źródło: Archiwum UAM, sygn. 15/308

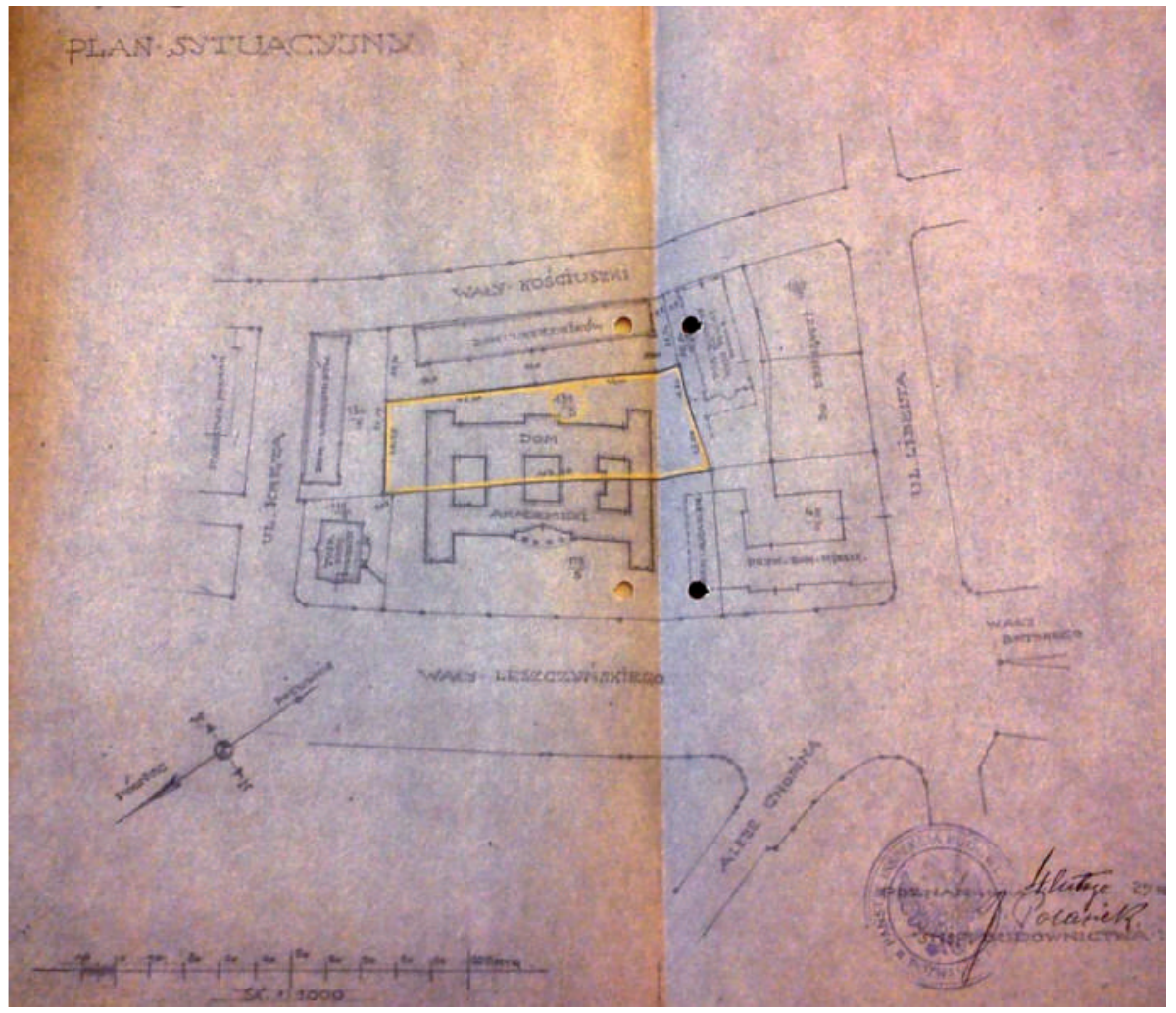

Ryc. 2. Rok 1927. Plan sytuacyjny domu akademickiego. Źródło: Archiwum UAM, sygn. $15 / 308$ 
kowej. Uniwersytet zapytał o zdanie Komitet Wojewódzki, ten jednak w liście do Rektora uznał cenę za zbyt wygórowaną ${ }^{34}$. Sprawa w tym miejscu utknęła. Powracała ona jeszcze kilkakrotnie, jednak ostatecznie nie została zrealizowana. Warto nadmienić, że w 1925 r. Komisja Rozbudowy Miasta Poznania stwierdziła, że „nie zalecałoby się przekazywać gruntu fiskalnego na własność Uniwersytetu"35. W 1936 r. Komitet Wojewódzki znajdował się już w stanie likwidacji i miał wówczas przekazać prawa do budynku Uniwersytetowi ${ }^{36}$. Okazuje się jednak, że do tego nie doszło, jeżeli w 1938 r. Uniwersytet zwracał się do Ministerstwa Wyznań i Oświecenia Religijnego z prośbą o wznowienie sprawy sprzedaży gruntów przy Wałach Leszczyńskiego $6^{37}$.

Nie był to jedyny budowany w tym samym czasie akademik. Równolegle powstawał dom na Sołaczu, który również zaprojektował Sławski, przeznaczony dla studentów Wydziału Rolniczo-Leśnego. Pośpieszne budowanie domu akademickiego i nieuregulowanie prawne jego sytuacji wynikało przede wszystkim z konieczności szybkiej odpowiedzi na zapotrzebowanie na kwaterunek dla studentów i chęci zadbania o nich. Zapotrzebowanie takie wynikało z dużej liczby młodzieży przyjezdnej. To z kolei może świadczyć o popularności poznańskiej uczelni. Biorąc pod uwagę, że na studiowanie potrzebowano wówczas sporo pieniędzy ze względu na wpisowe oraz płatne egzaminy, popularność ta jest dowodem na pragnienie zdobywania wiedzy w odrodzonej Polsce.

Po wojnie Wały Leszczyńskiego otrzymały nazwę ul. Stalingradzkiej, przemianowanej po 1989 r. na aleję Niepodległości. Dom akademicki dostał imię Hanki Sawickiej, z którego została dzisiaj po prostu „Hanka”. Akademik ten wpisał się na trwałe w życie uniwersyteckie i panoramę Poznania, do dziś goszcząc w swoich murach studentów.

34 Działalność Poznańskiego Komitetu, s. 48-49.

35 Tamże, s. 50.

${ }^{36}$ Archiwum UAM, sygn. 15/303, Rektorat, Budowa domu akademickiego UP 1930-1939, 1 maja $1936 \mathrm{r}$.

37 Tamże, 25 września 1938 r. 
Magdalena Heruday-Kiełczewska

\title{
Powstanie domu akademickiego przy Wałach Leszczyńskiego 6
}

\begin{abstract}
Streszczenie
Uniwersytet Poznański, powstały w 1919 r., szybko odczuł potrzebę powstania domu akademickiego dla przybywających do Poznania studentów. W latach 1925-1929, wysiłkiem Poznańskiego Komitetu Wojewódzkiego do Spraw Pomocy Polskiej Młodzieży Akademickiej, przy Wałach Leszczyńskiego powstał istniejący do dziś gmach (obecnie akademik "Hanka” przy al. Niepodległości), w którym mieściły się studenckie pokoje oraz pomieszczenia, takie jak czytelnia, kaplica czy stołówka. Budowa domu była inicjatywą, którą wsparło całe społeczeństwo Wielkopolski, i która przysłużyła się nie tylko młodzieży, ale również posłużyła jako kwatera dla gości przybywających na Powszechną Wystawę Krajową. Pomimo iż w zamyśle właścicielem budynku miał być Uniwersytet. Do 1939 r. nie udało się jednak uregulować kwestii własności, mimo usilnych starań Rektora.
\end{abstract}

\section{The History of the Dormitory at Wały Leszczyńskiego 6}

\begin{abstract}
Poznań University was established in 1919 and it quickly became clear that it was necessary to build dormitories for incoming students. Between 1925 and 1929, with the efforts of Poznań Voivodeship Committee for Helping Young Polish Students, the building that exists until the present day (now "Hanka" dormitory at Aleje Niepodległości) was built at Wały Leszczyńskiego. It had rooms for students and common rooms, e. g. a reading room, a chapel and a canteen. The construction was an initiative supported by the community of Greater Poland and it catered not only for students' needs, but also for guests coming to Poznan to see the Polish General Exhibition. Initially, the University was supposed to be the owner of the building. However, until 1939, it was impossible to regulate the ownership, despite Vice-chancellor's efforts.
\end{abstract}

